Acta Crystallographica Section D

Biological

Crystallography

ISSN 0907-4449

\title{
Ultrahigh-resolution crystal structures of Z-DNA in complex with $\mathrm{Mn}^{2+}$ and $\mathrm{Zn}^{2+}$ ions
}

\author{
Pawel Drozdzal, Miroslaw Gilski, Ryszard Kierzek, Lechoslaw Lomozik \\ and Mariusz Jaskolski
}

Acta Cryst. (2013). D69, 1180-1190

Copyright (C) International Union of Crystallography

Author(s) of this paper may load this reprint on their own web site or institutional repository provided that this cover page is retained. Republication of this article or its storage in electronic databases other than as specified above is not permitted without prior permission in writing from the IUCr.

For further information see http://journals.iucr.org/services/authorrights.html

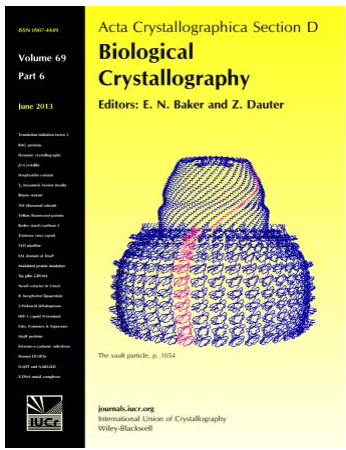

Acta Crystallographica Section D: Biological Crystallography welcomes the submission of papers covering any aspect of structural biology, with a particular emphasis on the structures of biological macromolecules and the methods used to determine them. Reports on new protein structures are particularly encouraged, as are structure-function papers that could include crystallographic binding studies, or structural analysis of mutants or other modified forms of a known protein structure. The key criterion is that such papers should present new insights into biology, chemistry or structure. Papers on crystallographic methods should be oriented towards biological crystallography, and may include new approaches to any aspect of structure determination or analysis. Papers on the crystallization of biological molecules will be accepted providing that these focus on new methods or other features that are of general importance or applicability.

Crystallography Journals Online is available from journals.iucr.org 
Acta Crystallographica Section D

Biological

Crystallography

ISSN 0907-4449

Pawel Drozdzal, ${ }^{a}$ Miroslaw Gilski, ${ }^{\text {a,b }}$ Ryszard Kierzek, Lechoslaw Lomozik $^{a *}$ and Mariusz Jaskolski ${ }^{\mathbf{a}, \mathbf{b}}$ *

${ }^{\text {a}}$ Faculty of Chemistry, A. Mickiewicz University, Poznan, Poland, and ${ }^{\mathbf{b}}$ Institute of Bioorganic Chemistry, Polish Academy of Sciences, Poznan, Poland

Correspondence e-mail: lomozik@amu.edu.pl, mariuszj@amu.edu.pl

\section{Ultrahigh-resolution crystal structures of Z-DNA in complex with $\mathrm{Mn}^{2+}$ and $\mathrm{Zn}^{2+}$ ions}

X-ray crystal structures of the spermine ${ }^{4+}$ form of the Z-DNA duplex with the self-complementary $\mathrm{d}(\mathrm{CG})_{3}$ sequence in complexes with $\mathrm{Mn}^{2+}$ and $\mathrm{Zn}^{2+}$ cations have been determined at the ultrahigh resolutions of 0.75 and $0.85 \AA$, respectively. Stereochemical restraints were only used for the sperminium cation (in both structures) and for nucleotides with dual conformation in the $\mathrm{Zn}^{2+}$ complex. The $\mathrm{Mn}^{2+}$ and $\mathrm{Zn}^{2+}$ cations at the major site, designated $M^{2+}(1)$, bind at the N7 position of G6 by direct coordination. The coordination geometry of this site was octahedral, with complete hydration shells. An additional $\mathrm{Zn}^{2+}(2)$ cation was bis-coordinated in a tetrahedral fashion by the N7 atoms of G10 and G12 from a symmetryrelated molecule. The coordination distances of $\mathrm{Zn}^{2+}(1)$ and $\mathrm{Zn}^{2+}(2)$ to the $\mathrm{O} 6$ atom of the guanine residues were 3.613 (6) and 3.258 (5) $\AA$, respectively. Moreover, a chloride ion was also identified in the coordination sphere of $\mathrm{Zn}^{2+}(2)$. Alternate conformations were observed in the $\mathrm{Z}-\mathrm{DNA}-\mathrm{Zn}^{2+}$ structure not only at internucleotide linkages but also at the terminal $\mathrm{C}^{\prime}-\mathrm{OH}$ group of G12. The conformation of the sperminium chain in the $\mathrm{Z}$-DNA- $\mathrm{Mn}^{2+}$ complex is similar to the spermine ${ }^{4+}$ conformation in analogous $\mathrm{Z}-\mathrm{DNA}-\mathrm{Mg}^{2+}$ structures. In the $\mathrm{Z}$-DNA- $\mathrm{Zn}^{2+}$ complex the sperminium cation is disordered and partially invisible in electron-density maps. In the $\mathrm{Z}$-DNA- $\mathrm{Zn}^{2+}$ complex the sperminium cation only interacts with the phosphate groups of the Z-DNA molecules, while in the Z-DNA- $\mathrm{Mn}^{2+}$ structure it forms hydrogen bonds to both the phosphate groups and DNA bases.

\section{Introduction}

Left-handed duplexes of Z-DNA with the self-complementary $\mathrm{d}(\mathrm{CG})_{3}$ sequence $^{\mathbf{1}}$ are remarkable for their potential to form crystals that diffract $\mathrm{X}$-rays to very high resolution. This has been documented in a number of crystallographic studies, including the recent publication of a metal-free crystal structure at a record-breaking resolution of $0.55 \AA$ (Brzezinski et al., 2011). Z-DNA crystals have been studied in complexes with metal cations and/or with biogenic polyamines. Positively charged counterions are essential for the electrostatic balance and conformational stability of the polyanionic nucleic acid structures. In particular, for the alternating $\mathrm{d}$ (pyrimidine/ purine) sequence, appropriate concentrations of polyamine or metal cations are essential for the $\mathrm{B} \rightarrow \mathrm{Z}$-form transition. Structures of Z-DNA as complexes with seven different polyamines have been deposited in the Protein Data Bank (PDB; Berman et al., 2000) and the Nucleic Acid Data Bank (NDB; Berman et al., 1992). The fully protonated sperminium
Received 27 February 2013 Accepted 20 March 2013

PDB References: Z-DNA in complex with $\mathrm{Mn}^{2+}$, 4hig; Z-DNA in complex with $\mathrm{Zn}^{2+}$, 4hif

\footnotetext{
${ }^{1}$ In this notation, $\mathrm{d}(\mathrm{CG})_{3}$ refers to the deoxynucleotide sequence of a single (hexameric) chain, i.e. $\mathrm{d}(\mathrm{CGCGCG})$.
} 
tetracation [Spk; spermine ${ }^{4+} ;{ }^{+} \mathrm{H}_{3} \mathrm{~N}\left(\mathrm{CH}_{2}\right)_{3} \mathrm{NH}_{2}^{+}\left(\mathrm{CH}_{2}\right)_{4} \mathrm{NH}_{2}^{+-}$ $\left.\left(\mathrm{CH}_{2}\right)_{3} \mathrm{NH}_{3}^{+}\right]$is the most common biogenic polyamine ion used to obtain Z-DNA crystals. Generally, when one molecule of spermine ${ }^{4+}$ is accommodated in the crystal structure of Z-DNA, it can interact with the DNA atoms in two different interhelical modes, leading to two different polymorphs with very similar crystallographic parameters (space group $P 2_{1} 2_{1} 2_{1}$ and similar unit-cell dimensions). The two crystal forms of Z-DNA differ in the rotation and translation of the DNA duplex about the $c$ axis. They were denoted $\mathrm{A}$ and $\mathrm{B}$ by Brzezinski et al. (2011). It should be noted that the interactions of spermine ${ }^{4+}$ with the Z-DNA duplexes may also differ slightly within the same crystal-packing variant.

Despite having apparently similar chemical properties, the $\mathrm{Mg}^{2+}, \mathrm{Mn}^{2+}$ and $\mathrm{Zn}^{2+}$ cations play unique roles in biological systems (Bock et al., 1999). Many enzyme-catalyzed reactions involving nucleic acids require divalent metal-ion cofactors to promote activity (Cowan, 1998). The chemistry of $\mathrm{Mn}^{2+}$ is similar to that of $\mathrm{Mg}^{2+}$ because these two ions have similar ionic radii, borderline hard-soft character and a preference for six ligands in octahedral coordination geometry. For these reasons, $\mathrm{Mn}^{2+}$ is commonly used as a spectroscopically active substitute for $\mathrm{Mg}^{2+}$ in biochemical and biophysical NMR studies and also in crystallography (see, for example, Bujacz et al., 1996). However, it has also been observed that the stoichiometry and coordination mode of $\mathrm{Mn}^{2+}$ or other transition metals, such as $\mathrm{Co}^{2+}, \mathrm{Fe}^{2+}$ or $\mathrm{Zn}^{2+}$, may differ from those of $\mathrm{Mg}^{2+}$. These cations often lead to increased levels of catalytic activity of the native enzymes as well as their mutants with altered Asp and/or Glu residues at the metal-coordination sites (Cowan, 1998). In $\mathrm{Mn}^{2+}$ complexes, water in the inner coordination sphere is more readily replaced by other groups than it is in the corresponding $\mathrm{Mg}^{2+}$ complexes. A comparative analysis of the crystal structures in the Cambridge Structural Database (CSD; Allen, 2002) and the PDB demonstrates that $\mathrm{Mn}^{2+}$ binds more readily than $\mathrm{Mg}^{2+}$ to sites containing nitrogen in addition to oxygen because $\mathrm{Mg}^{2+}$ has a stronger preference for oxygen ligands (Bock et al., 1999). The authors of this study also noted that experimentally $\mathrm{Zn}^{2+}$ is not more effective in substituting for $\mathrm{Mg}^{2+}$ than $\mathrm{Mn}^{2+}$, as would have been expected from analysis of the ionic radii and metal ionoxygen distances in hexahydrated complexes. This observation can be linked to the fact that $\mathrm{Zn}^{2+}$ is more flexible with respect to its coordination number and forms complexes with four to six ligands. This suggests that other factors (in addition to size and charge) may influence the specificity of metal-ion interactions with biomolecules.

Among all Z-DNA metal-cation complexes, the largest number of crystal structures is available for magnesium complexes. It is well known that metal cations (especially transition metals) prefer to bind to the N7 atom of guanine. The binding of transition-metal ions to Z-DNA may lead to conversion between the $\mathrm{Z}_{\mathrm{I}}$ and $\mathrm{Z}_{\mathrm{II}}$ backbone geometries via a mechanism described for $\mathrm{Mg}^{2+}$ complexes (Gessner et al., 1985). In some of the Z-DNA structures, bridging metal ions such as $\mathrm{Ba}^{2+}, \mathrm{Mn}^{2+}, \mathrm{Co}^{2+}$ and $\mathrm{Cu}^{2+}$ were observed between two complementary DNA bases (Geierstanger et al., 1991; Gao et al., 1993; Jean et al., 1993; Mandal et al., 2012). In addition, structures of Z-DNA with coordination complexes of $\mathrm{Co}^{3+}$ (Harper et al., 1998), $\mathrm{Ru}^{3+}$ (Ho et al., 1987; Bharanidharan et al., 2007) and $\mathrm{Pt}^{2+}$ (Parkinson et al., 1995) have been deposited in the PDB. Although Z-DNA-Co ${ }^{2+}$ and Z-DNA-Spk- $\mathrm{Co}^{2+}$ complex structures have also been reported in the literature, their coordinates are not available in the databases. It is remarkable that in PDB entry 3g2r (S. Venkadesh, P. K. Mandal, R. Kannan \& N. Gautham, unpublished work), $\mathrm{Mn}^{2+}$ is coordinated by the $\mathrm{O} 6$ atoms (with distances of $2.44 \AA$ ) of two guanine residues.

Although the ultrahigh-resolution crystal structure of metal-free Z-DNA indicates that the left-handed duplex is very regular and extremely rigid (Brzezinski et al., 2011), the presence of metal cations may induce disorder of the phosphate groups of the Z-DNA and force the sugar-phosphate backbone to assume alternate positions (Subirana \& SolerLopez, 2003; Bharanidharan et al., 2007). As shown by Bae et al. (2011), the dynamic nature of the DNA structure plays a critical role in the genome-wide search for recognition sites by proteins. Such a recognition process is believed to be initiated by spontaneous fluctuations of DNA structure rather than by active inducement by proteins. In the present study, we show how the binding of spermine and different metal ions might influence the backbone dynamics of DNA. It should be noted that despite the large volume of literature and structural data on Z-DNA-polyamine ${ }^{m+}-$ metal $^{n+}$ structures, direct coordina- $^{-}$ tion between the metal ions and the polyamine molecules has never been observed, apart from in nucleotide-polyamine ${ }^{m+}-$ metal $^{n+}$ systems (Lomozik et al., 2005).

In the present study, we describe two very high resolution crystal structures of the spermine ${ }^{4+}$ form of $d(C G)_{3}$ Z-DNA in complex with $\mathrm{Mn}^{2+}$ and $\mathrm{Zn}^{2+}$ ions. In this paper, we discuss the coordination modes of the $\mathrm{Mn}^{2+}, \mathrm{Zn}^{2+}$ and Spk cations with Z-DNA and compare them with the previously reported interactions in analogous Z-DNA structures. We also examine the influence of the metal ions on the conformational stability of the Z-DNA molecule.

\section{Materials and methods}

\subsection{Oligonucleotide synthesis, purification and crystallization}

A DNA hexamer with the d(CGCGCG) sequence was synthesized on an Applied Biosystems DNA/RNA synthesizer using phosphoramidite chemistry. Oligonucleotides were cleaved from the solid support using aqueous ammonia and were incubated overnight at $328 \mathrm{~K}$ for deprotection. Purification was performed by thin-layer chromatography (TLC) on silica-gel plates $(0.5 \mathrm{~mm}$; Merck) in 1-propanol:ammonia: water [55:35:10(v:v:v); Xia et al., 1998]. A $1.5 \mathrm{~m} M$ water solution of the DNA duplex was annealed at $338 \mathrm{~K}$ for $10 \mathrm{~min}$. Single crystals of the DNA were grown at $292 \mathrm{~K}$ by the hanging-drop vapour-diffusion method by mixing $2 \mu \mathrm{l}$ nucleic acid solution and $2 \mu \mathrm{l}$ precipitating solution consisting of $10 \%(v / v) \quad( \pm)-2-m e t h y l-2,4-p e n t a n e d i o l \quad(M P D), \quad 40 \mathrm{mM}$ 
Table 1

Data-collection and refinement statistics for the $\mathrm{d}(\mathrm{CG})_{3}-\mathrm{Spk}-\mathrm{Mn}^{2+}$ and $\mathrm{d}(\mathrm{CG})_{3}-\mathrm{Spk}-\mathrm{Zn}^{2+}$ structures.

Values in parentheses are for the last resolution shell.

\begin{tabular}{|c|c|c|}
\hline & $\mathrm{d}(\mathrm{CG})_{3}-\mathrm{Spk}-\mathrm{Mn}^{2+}$ & $\mathrm{d}(\mathrm{CG})_{3}-\mathrm{Spk}-\mathrm{Zn}^{2+}$ \\
\hline \multicolumn{3}{|l|}{ Data collection } \\
\hline Radiation source & $\begin{array}{l}\text { X13, EMBL, Hamburg/ } \\
\text { 14.2, BESSY, Berlin }\end{array}$ & X11, EMBL, Hamburg \\
\hline Wavelength $(\AA)$ & $0.8010 / 0.9184$ & 0.8174 \\
\hline Temperature (K) & $100 / 100$ & 100 \\
\hline Space group & $P 2_{1} 2_{1} 2_{1}$ & $P 2_{1} 2_{1} 2_{1}$ \\
\hline Unit-cell parameters $(\AA)$ & $\begin{array}{l}a=17.73, b=31.44 \\
\quad c=43.94\end{array}$ & $\begin{array}{l}a=17.79, b=30.91 \\
\quad c=44.20\end{array}$ \\
\hline Resolution range $(\AA)$ & $25.57-0.75(0.81-0.75)$ & $17.98-0.85(0.90-0.85)$ \\
\hline Effective resolution $\dagger(\AA)$ & 0.78 & 0.87 \\
\hline No. of reflections & 27718 & $19834 \ddagger$ \\
\hline Completeness (\%) & $87.5(43.7)$ & $89.3(67.0)$ \\
\hline Multiplicity & $5.75(1.82)$ & $5.59(3.72)$ \\
\hline$\langle I / \sigma(I)\rangle$ & $22.05(8.00)$ & $19.70(3.54)$ \\
\hline$R_{\text {merge }} \S(\%)$ & $5.6(6.0)$ & $5.4(26.8)$ \\
\hline Wilson $B$ factor $\left(\AA^{2}\right)$ & 4.87 & 8.13 \\
\hline \multicolumn{3}{|l|}{ Refinement } \\
\hline Refinement program & SHELXL & SHELXL \\
\hline Resolution $(\AA)$ & $25.57-0.75$ & $17.98-0.85$ \\
\hline \multicolumn{3}{|l|}{ No. of reflections } \\
\hline Working set & 467219 & 35508 ब \\
\hline Test set & 1009 & 1004 \\
\hline$R / R_{\text {free }} \dagger \dagger(\%)$ & $7.06 / 8.10$ & $9.22 / 11.30$ \\
\hline \multicolumn{3}{|l|}{ No. of atoms } \\
\hline Nucleic acid & 240 & 240 \\
\hline Solvent & 92 & 75 \\
\hline Metal & 1 & 2 \\
\hline \multicolumn{3}{|l|}{$\langle B\rangle\left(\AA^{2}\right)$} \\
\hline Nucleic acid chain $A$ & 2.53 & 6.66 \\
\hline Nucleic acid chain $B$ & 2.24 & 6.15 \\
\hline Solvent & 9.56 & 14.55 \\
\hline Spk & 6.80 & 17.27 \\
\hline Metal & 1.89 & 5.93 \\
\hline \multicolumn{3}{|c|}{ R.m.s. deviations from ideal } \\
\hline Bond lengths $(\AA)$ & 0.012 & 0.027 \\
\hline Angle distances $(\AA)$ & 0.029 & 0.059 \\
\hline
\end{tabular}

$\dagger$ The resolution of a hypothetical $100 \%$ complete data set calculated using DATAMAN (Kleywegt \& Jones, 1996). $\quad$ B Bijvoet pairs merged. $\quad \& R_{\text {merge }}=\sum_{h k l} \sum_{i} \mid I_{i}(h k l)-$ $\langle I(h k l)\rangle \mid / \sum_{h k l} \sum_{i} I_{i}(h k l)$, where $I_{i}(h k l)$ is the intensity of observation $i$ of reflection $h k l$. ๆ Bijvoet pairs separate. $\dagger \uparrow R=\sum_{h k l}|| F_{\text {obs }}|-| F_{\text {calc }}|| / \sum_{h k l}\left|F_{\text {obs }}\right|$ for all reflections, where $F_{\text {obs }}$ and $F_{\text {calc }}$ are observed and calculated structure factors. $R_{\text {free }}$ is calculated analogously for the test reflections, which were randomly selected and excluded from the refinement.

sodium cacodylate $\mathrm{pH}$ 6.0, $80 \mathrm{~m} M \mathrm{KCl}, 12 \mathrm{~m} M \mathrm{NaCl}, 12 \mathrm{~m} M$ sperminium tetrachloride. The drops were equilibrated against $0.5 \mathrm{ml} 35 \%(v / v)$ MPD. Crystals appeared within one week and grew to dimensions of $0.3 \times 0.1 \times 0.1 \mathrm{~mm}$. The best crystals were used for metal-ion soaking. For metal-ion soaking, the crystals were placed in $2 \mu \mathrm{l}$ reservoir solution mixed with $2 \mu \mathrm{l}$ $5 \mathrm{mM} \mathrm{MnCl} 2$ or $\mathrm{ZnCl}_{2}$ for one week.

\subsection{Data collection, structure solution and refinement}

X-ray diffraction data for the $\mathrm{Mn}^{2+}$ and $\mathrm{Zn}^{2+}$ complexes were collected to resolutions of 0.75 and $0.85 \AA$, respectively, on the EMBL beamlines X13 and X11 at the DESY synchrotron in Hamburg and on beamline 14.2 at BESSY in Berlin (Table 1). The crystals were vitrified in a stream of cold nitrogen gas at $100 \mathrm{~K}$. The mother liquor served as a cryoprotectant solution. The complete data set for the Z-DNA$\mathrm{Spk}-\mathrm{Mn}^{2+}$ complex was measured using two crystals. The data collected on BESSY beamline 14.2 extended to $0.94 \AA$ resolution and were recorded in four passes using different crystalto-detector distances and exposure times to ensure reliable measurement of the high-resolution data and of the strong low-resolution reflections and to avoid oversaturation of the MAR225 detector. Passes 1, 2, 3 and 4 were collected with crystal-to-detector distances of $350,250,140$ and $70 \mathrm{~mm}$, maximum resolutions of 2.86, 1.99, 1.30 and $0.94 \AA$, and 120 , 120, 120 and 129 images, respectively; the oscillation was $1^{\circ}$ in each pass. The second crystal provided the outer resolution shell of data extending to $0.75 \AA$ resolution; this was recorded on DESY beamline X13 using a MAR165 detector in one pass of $480 \times 0.25^{\circ}$ images. Because the diffraction quality of the first crystal was not as good as that of the second crystal, the resolution of subset 4 was truncated at $1.4 \AA$ during scaling. Detailed statistics of the final merged data set are listed in Supplementary Table $\mathrm{S1}^{2}$. The diffraction data for the Z-DNA-Spk- $\mathrm{Zn}^{2+}$ crystal were collected to $0.85 \AA$ resolution on DESY beamline X11 using a MAR555 flat-panel detector. The dynamic range of the detector was adequate for measuring the weak and strong reflections in one pass of $720 \times$ $0.25^{\circ}$ images. The diffraction data for both structures were indexed, integrated and scaled using the $X D S$ package (Kabsch, 2010). The X-ray data statistics are summarized in Table 1 . The structures were solved by molecular replacement using Phaser (McCoy et al., 2007). PDB entry 1i0t (Tereshko et al., 2001) served as a search model. In the initial stages of refinement the models were refined using REFMAC5 (Murshudov et al., 2011) from the CCP4 program suite (Winn et al., 2011). Later, anisotropic refinement with SHELXL (Sheldrick, 2008) was performed using the full resolution of the diffraction data. At the wavelengths used in our experiments the imaginary components of the anomalous scattering $\left(f^{\prime \prime}\right)$ of $\mathrm{Mn}$ and $\mathrm{Zn}$ atoms are 0.909/1.163 and 1.827 electron units, respectively (Cromer, 1983). For this reason, refinement of both structures was carried out with unmerged Bijvoet pairs. This decision was also justified by the anomalous signal, which was clearly visible in the diffraction data sets, as illustrated for $\mathrm{Mn}^{2+}$ in Supplementary Table S1.

After each round of 50 cycles of conjugate-gradient leastsquares (CGLS) minimization, the Coot program (Emsley et $a l ., 2010)$ was used for visualization of electron-density maps and for manual rebuilding of the atomic models. $\mathrm{H}$ atoms were added at riding positions and were refined isotropically. The instruction AFIX_87 was used for refinement of the hydroxyl groups of the deoxyribose moieties. There was no attempt to model the $\mathrm{H}$ atoms of the water molecules. The models were validated using the free $R$ test (Brünger, 1992) and the NuCheck program (Feng et al., 1998). 1009 (2.11\%) and 1004 $(2.75 \%)$ reflections were selected at random and set aside for $R_{\text {free }}$ calculations for the $\mathrm{Mn}^{2+}$ and $\mathrm{Zn}^{2+}$ complexes, respectively. In the final round of refinement the test reflections were included in the work set. Stereochemical restraints on the

\footnotetext{
${ }^{2}$ Supplementary material has been deposited in the IUCr electronic archive (Reference: DZ5281). Services for accessing this material are described at the back of the journal.
} 
Table 2

Average base-pair and local base-pair step helical parameters for selected Z-DNA structures identified by their PDB codes (in parentheses).

\begin{tabular}{|c|c|c|c|c|c|c|c|c|c|}
\hline & $\begin{array}{l}\text { Helical twist } \\
\Omega_{\mathrm{h}}\left({ }^{\circ}\right)\end{array}$ & $\begin{array}{l}\text { Helical } \\
\text { rise }(\AA)\end{array}$ & $\begin{array}{l}\text { Inclination } \\
\eta\left({ }^{\circ}\right)\end{array}$ & $\begin{array}{l}\text { Tip } \\
\left(^{\circ}\right)\end{array}$ & $\begin{array}{l}\text { Tilt } \\
\left(^{\circ}\right)\end{array}$ & $\begin{array}{l}\text { Roll } \\
\left({ }^{\circ}\right)\end{array}$ & $\begin{array}{l}\text { Shift } \\
(\AA)\end{array}$ & $\begin{array}{l}\text { Slide } \\
(\AA)\end{array}$ & $\begin{array}{l}\text { Rise } \\
(\AA)\end{array}$ \\
\hline $\mathrm{d}(\mathrm{CG})_{3}-\mathrm{Spk}-\mathrm{Mn}^{2+}$ (this work) & -58.99 & 4.50 & 17.45 & 5.23 & 0.71 & -3.10 & -0.07 & 2.79 & 3.45 \\
\hline $\mathrm{d}(\mathrm{CG})_{3}-\mathrm{Spk}-\mathrm{Zn}^{2+}$ (this work) & -60.93 & 4.11 & 15.64 & 0.47 & -0.03 & -2.45 & -0.14 & 2.87 & 3.52 \\
\hline $\mathrm{d}(\mathrm{CG})_{3}-\mathrm{Spm}-\mathrm{Mg}^{2+}(1 \mathrm{ick})$ & -59.89 & 4.41 & 15.00 & 3.23 & 0.51 & -3.14 & -0.02 & 2.80 & 3.49 \\
\hline $\mathrm{d}(\mathrm{CG})_{3}-\mathrm{Spm}-\mathrm{Mg}^{2+}(2 \mathrm{dcg})$ & -59.81 & 4.29 & 12.81 & 1.61 & 0.32 & -3.14 & -0.03 & 2.81 & 3.49 \\
\hline $\mathrm{d}(\mathrm{CG})_{3}-\mathrm{Mg}^{2+}(1 \mathrm{dcg})$ & -60.28 & 4.48 & 13.92 & 0.10 & 0.02 & -2.77 & 0.01 & 2.84 & 3.55 \\
\hline \multirow[t]{2}{*}{$\mathrm{d}(\mathrm{CACGCG}): \mathrm{d}(\mathrm{CGCGTG})-\mathrm{Mn}^{2+}(3 \mathrm{fq} 5) \dagger$} & -58.72 & 3.99 & 11.45 & -12.58 & -0.76 & -1.46 & -0.02 & 2.77 & 3.62 \\
\hline & -60.10 & 3.94 & 7.94 & -12.42 & -0.81 & -1.85 & -0.03 & 2.91 & 3.69 \\
\hline \multirow[t]{2}{*}{$\mathrm{d}(\mathrm{CACGCG}): \mathrm{d}(\mathrm{CGCGTG})-\mathrm{Mn}^{2+}(4 \mathrm{dwy}) \dagger$} & -57.75 & 3.64 & 3.64 & -1.38 & -0.81 & -1.52 & -0.04 & 2.82 & 3.54 \\
\hline & -59.34 & 4.08 & 18.94 & -8.19 & 0.08 & -1.78 & 0.03 & 3.00 & 3.63 \\
\hline $\mathrm{d}(\mathrm{CACGCG}): \mathrm{d}(\mathrm{CGCGTG})-\mathrm{Mn}^{2+}(4 \mathrm{dy} 8)$ & -62.37 & 2.90 & 2.38 & -14.51 & -0.23 & -2.01 & -0.20 & 2.89 & 3.48 \\
\hline $\mathrm{d}(\mathrm{CG})_{3}-\mathrm{Cu}^{2+}(1 \mathrm{~d} 39)$ & -60.45 & 4.08 & 8.48 & -1.48 & 0.04 & -2.67 & 0.02 & 2.85 & 3.55 \\
\hline $\mathrm{d}(\mathrm{CG})_{3}-\mathrm{Spm}(3 \mathrm{p} 4 \mathrm{j})$ & -59.97 & 4.28 & 14.14 & 4.17 & 0.66 & -3.23 & 0.00 & 2.78 & 3.45 \\
\hline $\mathrm{d}(\mathrm{CG})_{3}-\mathrm{Spm}(1 \mathrm{i} 0 \mathrm{t})$ & -61.36 & 3.35 & 2.05 & 4.62 & 1.01 & -1.62 & -0.02 & 3.04 & 3.47 \\
\hline
\end{tabular}

$\dagger$ The values in these two rows refer to the two duplexes present in the asymmetric unit.

DNA moieties were only applied to fragments of the $\mathrm{Zn}^{2+}$ complex that exhibited alternate backbone conformations. The restraints were taken from Clowney et al. (1996), Gelbin et al. (1996) and Parkinson et al. (1996). Restraints for the sperminium cation (bond distances and angles only) were generated from the interatomic distance data of International Tables for Crystallography (Allen et al., 2006). Restraints controlled by the SHELXL instructions ISOR, SIMU and DELU were only applied to atoms of the sperminium tetracation and water molecules in both structures. In order to provide estimations of standard uncertainties in all individual refined parameters and of all derived geometrical parameters, one cycle of full-matrix least-squares minimization was calculated in the final stage of the refinement which included all reflections but no restraints.

The DNA backbone at the $\mathrm{G} 2$ and $\mathrm{C} 3-\mathrm{G} 4$ residues in the $\mathrm{d}(\mathrm{CG})_{3}-\mathrm{Spk}-\mathrm{Zn}^{2+}$ structure was modelled in two conformations designated I (major; 61 and 57\%) and II (minor; 39 and $43 \%$ ), respectively. Water molecules were included in the models manually based on $F_{\mathrm{o}}-F_{\mathrm{c}}$ electron density and stereochemical considerations. A large portion of the water molecules were refined with partial occupancy. Water occupancies that refined to close to unity were fixed at 1.0. The locations of the $\mathrm{Mn}^{2+}, \mathrm{Zn}^{2+}(1)$ and $\mathrm{Zn}^{2+}(2)$ ions coincide with the most prominent peaks in the anomalous difference Fourier maps of 32.3, 58.0 and 57.0 $\sigma$, respectively. The Z-DNA helical parameters were calculated using $3 D N A$ (Lu \& Olson, 2003) and the figures were generated using PyMOL (DeLano, 2002). The pseudorotation parameters used in this paper and in Supplementary Table S2 were calculated using the method of Jaskólski (1984).

\section{Results}

\subsection{Quality of the results}

The present structures of Z-DNA in complex with $\mathrm{Mn}^{2+}$ and $\mathrm{Zn}^{2+}$ ions were refined using data of 0.75 and $0.85 \AA$ resolution to final $R$ factors of 7.06 and $9.22 \%$, respectively. These results (especially for the $\mathrm{Mn}^{2+}$ complex) can be compared in terms of accuracy with the record-setting model of Z-DNA $(0.55 \AA$, $R=7.77 \%$ ) described by Brzezinski et al. (2011). The r.m.s.d. values for the DNA nucleotides between this structure (PDB entry $3 \mathrm{p} 4 \mathrm{j}$ ) and the present complexes with $\mathrm{Mn}^{2+}$ and $\mathrm{Zn}^{2+}$ are 0.146 and $0.289 \AA$ (conformation I of DNA in the $\mathrm{Zn}^{2+}$ complex) and $0.390 \AA$ (conformation II of DNA in the $\mathrm{Zn}^{2+}$ complex), respectively. The estimated standard uncertainties (e.s.u.s) of fully occupied DNA atomic positions in the $\mathrm{Mn}^{2+}$ structure are in the ranges $0.006-0.012 \AA$ for $\mathrm{C}$ atoms, $0.005-$ $0.008 \AA$ for N atoms, $0.004-0.019 \AA$ for $\mathrm{O}$ atoms and 0.002 $0.004 \AA$ for $\mathrm{P}$ atoms. The e.s.u.s for the $\mathrm{Zn}^{2+}$ structure are larger and are 0.011-0.028 $\AA$ for C atoms, 0.009-0.015 $\AA$ for $\mathrm{N}$ atoms, 0.008-0.023 $\AA$ for $\mathrm{O}$ atoms and 0.004-0.007 $\AA$ for $\mathrm{P}$ atoms. As expected, the positional uncertainties for the metal cations are lower: $0.001 \AA$ for $\mathrm{Mn}^{2+}$ and $0.001-0.002 \AA$ for $\mathrm{Zn}^{2+}$.

\subsection{Helix parameters and overall structure}

The asymmetric unit of both duplexes contains a hexameric DNA duplex, with the nucleotides numbered $\mathrm{C} 1, \mathrm{G} 2, \ldots, \mathrm{G} 6$ and $\mathrm{C} 7, \mathrm{G} 8, \ldots, \mathrm{G} 12$. The base-pair scheme is $\mathrm{C} 1 \cdot \mathrm{G} 12$, $\mathrm{G} 2 \cdot \mathrm{C} 11, \ldots, \mathrm{G} 6 \cdot \mathrm{C} 7$, i.e. the DNA oligonucleotides forming the duplex are numbered in an antiparallel fashion. The overall structural parameters of the DNA moieties of the $\mathrm{d}(\mathrm{CG})_{3}-\mathrm{Spk}-\mathrm{Mn}^{2+}$ and $\mathrm{d}(\mathrm{CG})_{3}-\mathrm{Spk}-\mathrm{Zn}^{2+}$ complexes classify them within the Z-DNA family. Comparisons of the helical parameters and base-pair geometries for the present and the previously reported Z-DNA complexes are summarized in Table 2. The r.m.s. deviations in atomic positions between the duplexes are $0.316 \AA$ when $\mathrm{d}(\mathrm{CG})_{3}-\mathrm{Spk}-\mathrm{Mn}^{2+}$ is compared with $\mathrm{d}(\mathrm{CG})_{3}-\mathrm{Spk}-\mathrm{Zn}^{2+}$ with the backbone in the major conformation (I) and $0.431 \AA$ for the minor conformation (II). Despite the overall similarity of the two complexes, there are also significant differences in several helical parameters and in the degree of sugar pucker (Supplementary Table S2). In contrast to the $\mathrm{Mn}^{2+}$ complex, there is a segment with $\mathrm{Z}_{\mathrm{II}}$ conformation (at the G10-C11 nucleotides) and disordered fragments along the DNA backbone of the $\mathrm{Zn}^{2+}$ complex. In addition, there are also packing differences related to the 


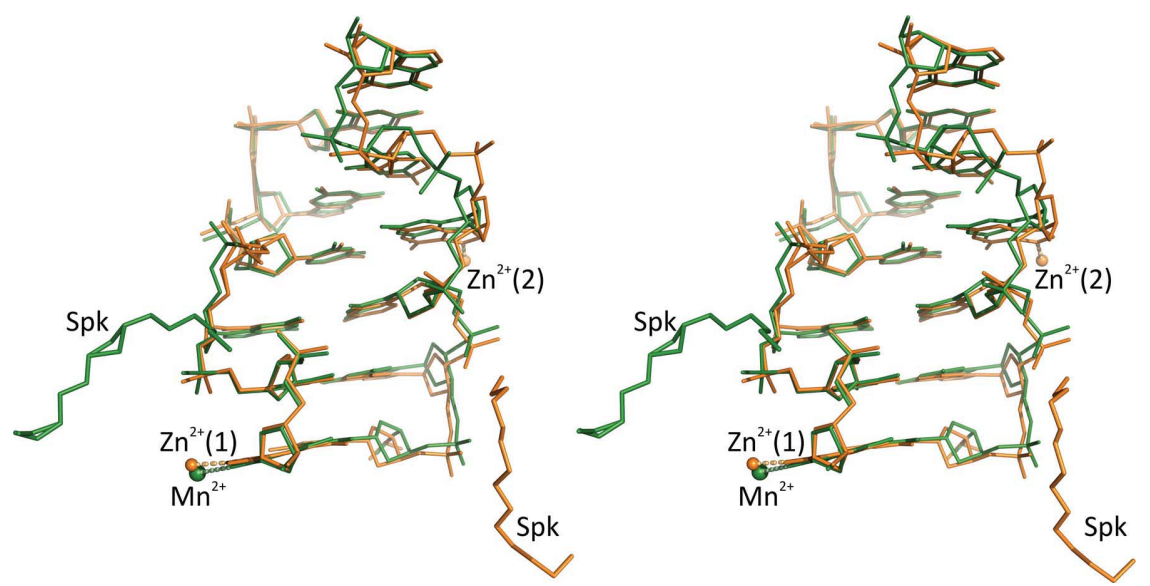

Figure 1

Stereoview of the $\mathrm{Mn}^{2+}$ (green) and $\mathrm{Zn}^{2+}$ (orange) complexes plotted in their common system of coordinates. Note the completely different location of the Spk molecule.

(C3G4-C9G10), the values of the inclination $(\eta)$ parameter are $29.64^{\circ}$ for $\mathrm{d}(\mathrm{CG})_{3^{-}}$ Spk- $\mathrm{Mn}^{2+}$ and $63.77^{\circ}$ for $\mathrm{d}(\mathrm{CG})_{3}-\mathrm{Spk}-\mathrm{Zn}^{2+}$. The width of the minor groove at step 3 of the $\mathrm{d}(\mathrm{CG})_{3}-\mathrm{Spk}^{-\mathrm{Mn}^{2+}}$ complex is $1.2 \AA$ narrower compared with the same step in the $\mathrm{d}(\mathrm{CG})_{3}-\mathrm{Spk}-\mathrm{Zn}^{2+}$ complex $(8.5 \AA)$. In addition, with respect to step 3 , large differences in the values of the $x$ displacement are observed between the $\mathrm{Mn}^{2+}$ and $\mathrm{Zn}^{2+}$ complexes. The values are $-26.29 \AA$ for the structure in complex with $\mathrm{Mn}^{2+}$ and $11.88 \AA$ for the structure in complex with $\mathrm{Zn}^{2+}$.

The C3.G10 and G4.C9 base pairs are significantly buckled, as evident from the relatively large angle $\kappa$ (buckle) between the cytosine and guanine bases within these base pairs. In the $\mathrm{d}(\mathrm{CG})_{3}-\mathrm{Spk}-\mathrm{Zn}^{2+}$

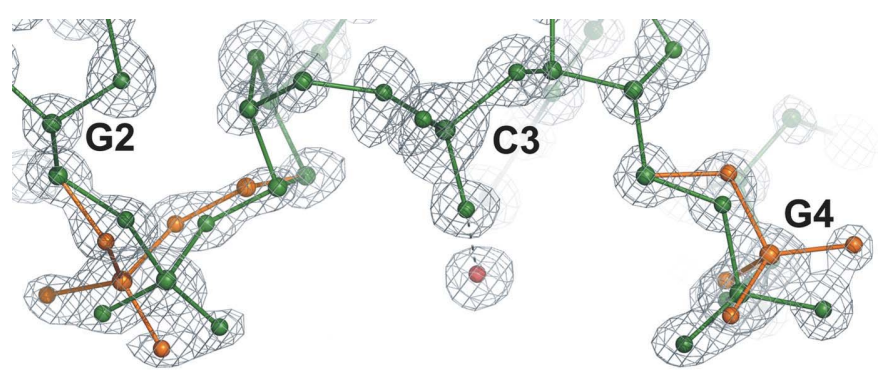

(a)

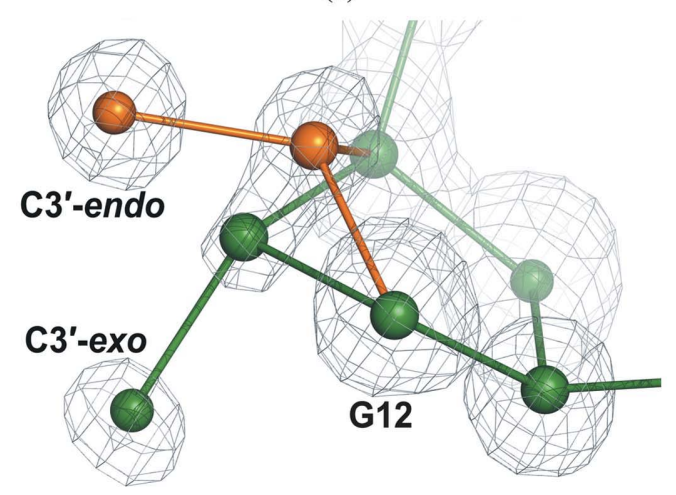

(b)

Figure 2

(a) A fragment of the DNA duplex in the $\mathrm{Zn}^{2+}$ complex between DNA bases $\mathrm{G} 2$ and G4 with two alternative backbone conformations (I, green; II, orange) shown as a $2 F_{\mathrm{o}}-F_{\mathrm{c}}$ map contoured at $2.0 \sigma$. (b) A portion of the DNA duplex in the $\mathrm{Zn}^{2+}$ complex at base G12 with two alternative backbone conformations (I, green; II, orange) shown as a $2 F_{\mathrm{o}}-F_{\mathrm{c}}$ map contoured at $1.5 \sigma$.

different position of the spermine ${ }^{4+}$ polycation relative to the DNA hexamer (Fig. 1). All of these aspects will be discussed in detail in the following sections.

The most pronounced differences in the helical parameters between the DNA molecules in $\mathrm{d}(\mathrm{CG})_{3}-\mathrm{Spk}-\mathrm{Mn}^{2+}$ and $\mathrm{d}(\mathrm{CG})_{3}-\mathrm{Spk}-\mathrm{Zn}^{2+}$ are visible in the $x$ and $y$ displacements, tip and inclination ( $\mathrm{Lu} \&$ Olson, 2003). These values vary from step to step and significant differences are observed at the first, intermediate and last steps in the two complexes. At step 3 complex the $\mathrm{C} 3 \cdot \mathrm{G} 10$ base pair has $\kappa=10.88^{\circ}$ and the $\mathrm{G} 4 \cdot \mathrm{C} 9$ base pair has $\kappa=-9.98^{\circ}$. For the same base pairs in the $\mathrm{d}(\mathrm{CG})_{3}-\mathrm{Spk}-\mathrm{Mn}^{2+}$ complex the amplitudes are smaller and the $\kappa$ values are 5.26 and $-8.23^{\circ}$, respectively. The $\mathrm{ZpH}$ parameters [equal to half of the projection on the local helical axis of the vector $\mathrm{P}\left(\mathrm{II}_{\text {strand }}\right) \rightarrow \mathrm{P}\left(\mathrm{I}_{\text {strand }}\right)$ that links the $\mathrm{P}$ atoms on the two strands forming a given base-pair step] at step 3 of the $\mathrm{d}(\mathrm{CG})_{3}-\mathrm{Spk}-\mathrm{Zn}^{2+}$ structure are close to the value of $4 \AA$ given by Lu \& Olson (2003). The values are 3.91 and $3.77 \AA$ for the [C3(I)G4(I)-C9G10] and [C3(II)G4(II)-C9G10] steps, respectively. These $\mathrm{ZpH}$ values for step 3 in the $\mathrm{d}(\mathrm{CG})_{3}-\mathrm{Spk}-$ $\mathrm{Zn}^{2+}$ structure in both conformations are distinctly different from the $\mathrm{ZpH}$ value of $0.50 \AA$ for the same step in the $\mathrm{d}(\mathrm{CG})_{3}{ }^{-}$ Spk-Mn ${ }^{2+}$ complex.

The DNA chain of the $\mathrm{d}(\mathrm{CG})_{3}-\mathrm{Spk}-\mathrm{Zn}^{2+}$ structure exhibits alternate conformations at the C1-G2, C3-G4, C7 and G12 nucleotides, which are clearly visible in the electron density (Fig. 2a). The major (I) and minor (II) conformations of C3 have $\mathrm{C1}^{\prime}$-exo and $\mathrm{C2}^{\prime}$-endo sugar puckers, respectively, with pseudorotation $(P)$ angles of 127.49 and $170.52^{\circ}$. Differences in sugar pucker are also observed at G12, where the conformations are (I) $\mathrm{C}^{\prime}$-exo $\left(P=193.85^{\circ}\right)$ and (II) $\mathrm{C}^{\prime}$-endo $\left(26.34^{\circ}\right)$ (Fig. $\left.2 b\right)$. The hydroxyl group at the $5^{\prime}$-terminus of the C7 nucleotide was also modelled in two positions $\left[\gamma(\mathrm{I})=51.0^{\circ}\right.$, $\left.\gamma(\mathrm{II})=-73.2^{\circ}\right]$. However, no alternate conformations were found in the electron-density maps of the $\mathrm{d}(\mathrm{CG})_{3}-\mathrm{Spk}-\mathrm{Mn}^{2+}$ structure. Formally, the sugar puckers of the G2 nucleotide fall in different regions of the pseudorotation wheel in the two structures, $\mathrm{C}^{\prime}$-endo in the $\mathrm{Mn}^{2+}$ complex and $\mathrm{C}^{\prime}$-exo in the $\mathrm{Zn}^{2+}$ complex, but the pseudorotation angles are similar at 31.12 and $37.67^{\circ}$, respectively. In both complexes the sugars at the 3'-terminus do not have the alternating $\mathrm{C}^{\prime}$-endo-C $3^{\prime}$-endo pucker for the pyrimidine-purine nucleotides that is typical of the Z-DNA structure, but all assume the $\mathrm{C} 2^{\prime}$-endo form. This behaviour has previously been described and explained as the effect of the 3'-terminal guanosine nucleotide (Gessner et al., 1989; Harper et al., 1998). The existence of unusual sugar puckers (such as $\mathrm{C1}^{\prime}$-exo, $\mathrm{C}^{\prime}$-exo and $\mathrm{C}^{\prime}$-exo) demonstrates 
Table 3

Coordination geometries around the metal ions in the $\mathrm{d}(\mathrm{CG})_{3}-\mathrm{Spk}-\mathrm{Mn}^{2+}$ and $\mathrm{d}(\mathrm{CG})_{3}-\mathrm{Spk}-\mathrm{Zn}^{2+}$ structures.

Standard uncertainties are shown in parentheses.

(a) $\mathrm{Mn}^{2+}$.

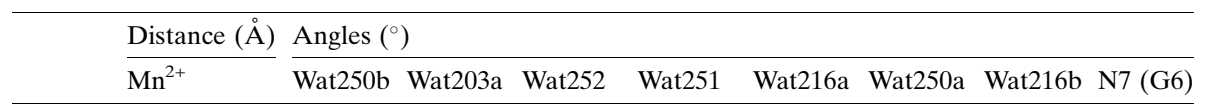

Wat250b $1.946(34)$

Wat203a $2.075(12)$

Wat252 $2.138(3)$

Wat251 $2.158(4)$

$148(1)$

$119(1)$

85 (1)

$52(1)$

$28(1)$

Wat250a 2.207 (4)

Wat216b 2.255 (27)

N7 (G6) 2.257 (3)

Wat203b $2.310(20)$

$79(1)$

$93(1)$ $155(1)$

\section{$92.2(3)$}

92.4 (4) $85.0(2)$

96.9 (3) $169.0(2) \quad 88.4(2)$

$174.3(3) \quad 92.3(2) \quad 91.5(2) \quad 79.1(2)$

$\begin{array}{lllll}69.7(7) & 161.9(6) & 95.4(7) & 27.9(6) & 105.8(6)\end{array}$

$91.6(4) \quad 93.8(2) \quad 175.9(2) \quad 92.2(2) \quad 84.6(1) \quad 87.0(7)$

$8.4(8) \quad 85.7$ (6) 97.0 (6) 103.9 (6) 171.0 (6) 76.3 (9) 87.0 (6)

(b) $\mathrm{Zn}^{2+}(1)$.

\begin{tabular}{|c|c|c|c|c|c|c|}
\hline & \multirow{2}{*}{$\frac{\text { Distance }(\AA)}{\mathrm{Zn}^{2+}(1)}$} & \multicolumn{5}{|c|}{ Angles $\left({ }^{\circ}\right)$} \\
\hline & & Wat205 & Wat234 & N7 (G6) & Wat235 & Wat201 \\
\hline Wat205 & $2.097(6)$ & & & & & \\
\hline Wat234 & $2.110(6)$ & 178.1 & & & & \\
\hline N7 (G6) & $2.112(6)$ & 92.9 (2) & $86.2(2)$ & & & \\
\hline Wat235 & $2.113(9)$ & $90.4(4)$ & $90.5(4)$ & 176.3 & & \\
\hline Wat201 & $2.116(6)$ & $87.1(3)$ & $91.3(3)$ & $90.2(2)$ & $88.2(4)$ & \\
\hline Wat210 & $2.140(8)$ & $93.3(3)$ & $88.4(3)$ & $92.2(3)$ & $89.3(4)$ & 177.5 \\
\hline
\end{tabular}

(c) $\mathrm{Zn}^{2+}(2)$

\begin{tabular}{|c|c|c|c|c|}
\hline & \multirow{2}{*}{$\frac{\text { Distance }(\AA)}{\mathrm{Zn}^{2+}(2)}$} & \multicolumn{3}{|c|}{ Angles $\left({ }^{\circ}\right)$} \\
\hline & & Wat233 & N7 (G10) & N7 $\left(\mathrm{G} 12^{\mathrm{ii}}\right)$ \\
\hline Wat233 & $1.944(5)$ & & & \\
\hline N7 (G10) & $1.990(6)$ & 111.0 (3) & & \\
\hline N7 $\left(\mathrm{G} 12^{\mathrm{ii}}\right)$ & $2.032(5)$ & 100.7 (2) & 109.7 (3) & \\
\hline $\mathrm{Cl}^{-}$ & 2.209 (2) & $110.2(2)$ & 112.9 (2) & 111.7 (2) \\
\hline
\end{tabular}

conformation of the phosphate group is also found at $\mathrm{G} 10-\mathrm{C} 11\left(\zeta=69.8^{\circ}\right)$ of the $\mathrm{Zn}^{2+}$ complex, where it may be related to the interaction with Wat 233 from the coordination sphere of the $\mathrm{Zn}^{2+}(2)$ cation. The backbone torsion angles for the alternate conformations of the phosphate groups at G2 and at G4 are typical of those found at pyrimidinepurine steps in the $\mathrm{Z}$ form (Svozil et al., 2008; Fig. 2a). On the other hand, there are differences in the $\alpha$ and $\gamma$ backbone angles between the two conformations at the $\mathrm{G} 2$ residue in the $\mathrm{Zn}^{2+}$ complex. The angles are $\alpha=70.3$ and $52.6^{\circ}$ and $\gamma=-179.7$ and $172.3^{\circ}$ for G2(I) and G2(II), respectively. The angles $\alpha$ and $\beta$ for the C5 nucleotide in both complexes are within the range attributed to the $\mathrm{Z}_{\mathrm{II}}$-type conformation. The angles are $\alpha=168.0$ and $173.3^{\circ}$ and $\beta=170.1$ and $146.1^{\circ}$ for the $\mathrm{Mn}^{2+}$ and $\mathrm{Zn}^{2+}$ complexes, respectively. While $Z_{I}$ and $Z_{I I}$ are two energetically allowed Z-DNA conformations, our structures corroborate previous implications that hydrated metal cations influence the $\mathrm{Z}_{\mathrm{I}} / \mathrm{Z}_{\mathrm{II}}$ pattern found in Z-DNA structures (Schneider et al., 1992).

\subsection{Coordination of the metal cations}

In this work, $\mathrm{Mn}^{2+}$ and $\mathrm{Zn}^{2+}$ ions were successfully soaked into preformed crystals of the spermine ${ }^{4+}$-only form of $\mathrm{d}(\mathrm{CG})_{3} \mathrm{Z}$-DNA. These cations

the plasticity of the DNA backbone. Such conformations are frequently found in protein-B/Z-DNA and protein-Z/Z-DNA complexes at key points of protein-DNA interactions. Such sugar conformations are often correlated with high buckle parameters (Eichman et al., 1999), as also demonstrated by our results.

Z-DNA oligomers can accommodate a set of two different phosphate conformations $\left(Z_{I}\right.$ and $\left.Z_{\text {II }}\right)$ without any clear sequence specificity (Harper et al., 1998; Thiyagarajan et al., 2005). It has been suggested that the $\mathrm{Z}_{\mathrm{II}}$ conformation is mainly related to the interaction of the phosphate group with a hydrated magnesium ion (Gessner et al., 1989), although the $\mathrm{Z}_{\mathrm{II}}$ conformation has also been reported to occur in the spermine-only form of Z-DNA (Egli et al., 1991; Bancroft et al., 1994). In the present structures, the $\mathrm{Z}_{\mathrm{II}}$ conformation can be assigned to G4-C5 in both the $\mathrm{d}(\mathrm{CG})_{3}-\mathrm{Spk}_{-} \mathrm{Mn}^{2+}(\zeta=$ $\left.62.6^{\circ}\right)$ and the $\mathrm{d}(\mathrm{CG})_{3}-\mathrm{Spk}-\mathrm{Zn}^{2+}\left(77.4^{\circ}\right)$ complexes. Similarly to other Z-DNA structures in which a hydrated metal ion is coordinated to N7 (G6), one of its coordinated water molecules is hydrogen bonded to a G4-C5 phosphate $\mathrm{O}$ atom, stabilizing the $\mathrm{Z}_{\mathrm{II}}$ conformation. The presence of the $\mathrm{Z}_{\mathrm{II}}$ preferentially coordinate to guanine N7 atoms, as previously described for the structures of Z-DNA with transition-metal ions (Kagawa et al., 1991; Gao et al., 1993). $\mathrm{Mn}^{2+}$ is found to interact with $\mathrm{G} 6$ by direct coordination to $\mathrm{N} 7$ at a distance of 2.257 (3) A (Table 3). The $\mathrm{Mn}^{2+}$ ion has octahedral geometry, with the remaining sites in the coordination sphere occupied by water molecules (Fig. 3a). However, three of the five water molecules coordinated by the manganese ion are disordered and were modelled in two complementary positions. In this context, the coordination sphere around $\mathrm{Mn}^{2+}$ can be considered as consisting of two alternative octahedra. These two octahedra have partial occupancy but share common modes (Table 3). The first octahedron $(a)$ includes water molecules with major occupancy $(0.78,0.77$ and 0.52$)$. The coordination bonds formed between $\mathrm{Mn}^{2+}$ and the five water molecules of octahedron $a$ range from 2.075 (12) to 2.207 (4) A. For the second (lower occupancy) octahedron (b), the coordination bonds formed between $\mathrm{Mn}^{2+}$ and the water molecules range from 1.946 (34) to 2.310 (20) A. The hydration sphere of $\mathrm{Mn}^{2+}$ is also involved in hydrogen-bonding interactions with the OP1 atom of C5, the O6 atom of G6 and 


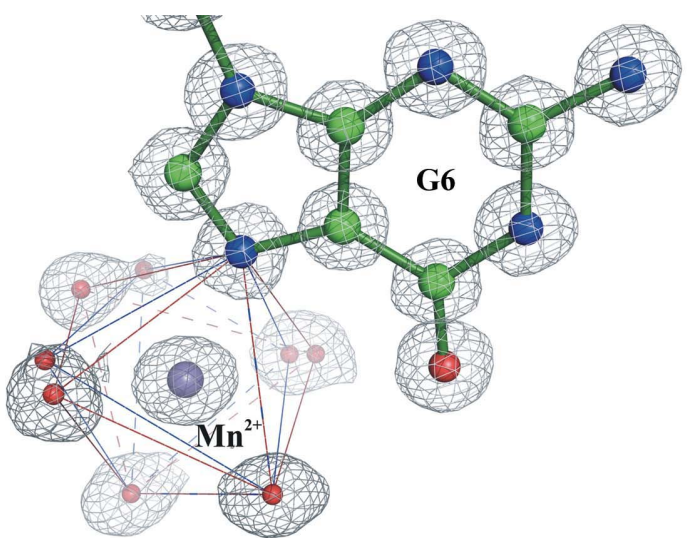

(a)

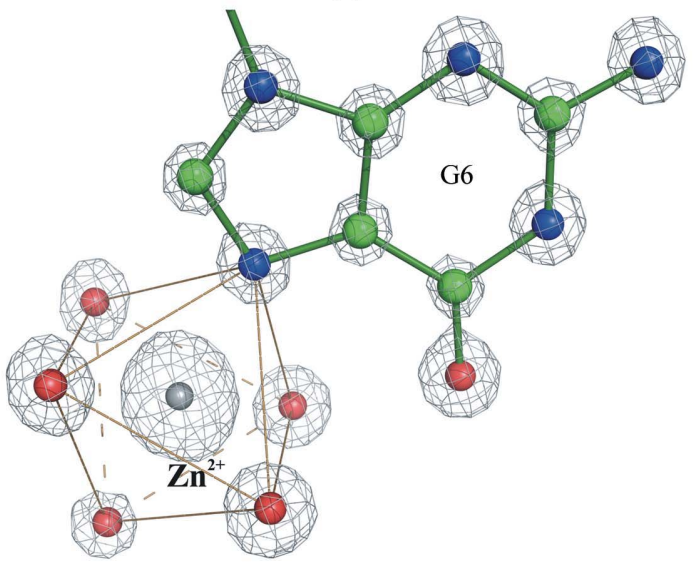

(b)

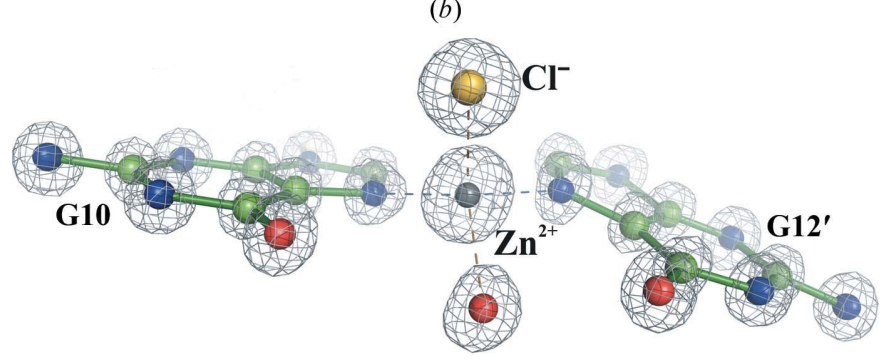

(c)

Figure 3

The octahedral coordination spheres of the hydrated complexes of $(a)$ $\mathrm{Mn}^{2+}$ (purple) and (b) $\mathrm{Zn}^{2+}$ (grey) at G6. The $2 F_{\mathrm{o}}-F_{\mathrm{c}}$ map is contoured at the 1.0 and $2.5 \sigma$ levels, respectively. (c) The tetrahedral coordination sphere of $\mathrm{Zn}^{2+}(2)$ (grey). The $2 F_{\mathrm{o}}-F_{\mathrm{c}}$ map is contoured at the $2 \sigma$ level. The coordination polyhedra are emphasized by outlines [the two alternatives in (a) are shown in red/blue].

the O6 atom of $\mathrm{G}^{\mathrm{i}}(3 / 2-x, 1-y, z+1 / 2)^{\mathbf{3}}$ from a symmetry-related molecule.

The N7 atom of G6 is also the preferred docking site for the octahedrally coordinated $\mathrm{Zn}^{2+}(1)$ cation (Fig. $3 b$ ). The distances from the central $\mathrm{Zn}^{2+}(1)$ ion to each of its six ligands (N7 and five water molecules) are similar and fall within the narrow range of 2.110 (6) to 2.140 (8) $\AA$ (Table 3). The $\mathrm{Zn}^{2+}(1)-\mathrm{N} 7$ bond is shorter [2.112 (6) $\AA$ ] than the corresponding bond for $\mathrm{Mn}^{2+}$. The coordination sphere of $\mathrm{Zn}^{2+}(1)$

\footnotetext{
${ }^{3}$ We wish to draw the readers' attention to the fact that the symmetry codes produced by popular macromolecular software are very often incorrect and have to be verified manually.
}

is more similar to a regular octahedron than the coordination sphere of $\mathrm{Mn}^{2+}$ and is fully ordered, without any indication of dual-occupancy water sites. In addition to the hydrogenbond interactions with OP1 (C5), O6 (G6) and O6 (G12 $\left.{ }^{\mathrm{i}}\right)$, the hydration sphere of $\mathrm{Zn}^{2+}(1)$ also interacts with OP2 (C5) and $\mathrm{N} 4\left(\mathrm{Cl}^{\mathrm{i}}\right)$; these additional interactions are absent in the $\mathrm{Mn}^{2+}$ hydration sphere, which may explain its more wobbly character.

The second zinc ion, $\mathrm{Zn}^{2+}(2)$, was found to coordinate simultaneously to the N7 sites of G10 and G12 $2^{\mathrm{ii}}(x+1 / 2$, $3 / 2-y, 1-z)$ from a symmetry-related molecule, with $\mathrm{Zn}^{2+}(2)-\mathrm{N} 7$ distances of $1.990(6)$ and 2.032 (5) $\AA$, respectively (Table 3; Fig. 3c). Wat233 and a $\mathrm{Cl}^{-}$ion complete the tetrahedral coordination sphere of $\mathrm{Zn}^{2+}(2)$. The $\mathrm{Zn}^{2+}(2)-\mathrm{Cl}^{-}$ bond length $[2.209$ (2) $\AA$ ] is only slightly shorter than the $\mathrm{Zn}^{2+}-\mathrm{Cl}^{-}$distances $(2.27 \AA)$ in the crystal of $\gamma-\mathrm{ZnCl}_{2}$ (Brehler, 1961). Wat233 is additionally hydrogen-bonded to O6 (G10) and O6 (G12 $\left.{ }^{\mathrm{ii}}\right)$, with $\mathrm{O} \cdots \mathrm{O}$ distances of 3.322 (7) and 2.656 (6) $\AA$, respectively. The Wat233 water molecule therefore bridges the $\mathrm{O} 6$ atoms of the same guanine residues that are also bridged by the $\mathrm{Zn}^{2+}(2)$ cation. The angles in the coordination sphere of $\mathrm{Zn}^{2+}(2)$ range from 100.7 (2) to $112.9(9)^{\circ}$. The distance between the two N7 atoms in the $\mathrm{Zn}^{2+}(2)$ coordination sphere is 3.289 (6) $\AA$.

It has been noted that close contacts between metal cations are quite common in Z-DNA structures (Harper et al., 1998). The two $\mathrm{Zn}^{2+}$ ions in the zinc complex are 6.307 (7) $\AA$ apart. Such an arrangement of the $\mathrm{Zn}^{2+}$ ions allows the O6 (G12 ${ }^{\mathrm{ii}}$ ) atom from a symmetry-related DNA molecule to act as a common node for hydrogen-bond formation with Wat201 and Wat233 from the hydration spheres of $\mathrm{Zn}^{2+}(1)$ and $\mathrm{Zn}^{2+}(2)$, respectively.

\subsection{Coordination of the sperminium tetracation}

The spermine molecule (Spm) exists in the fully protonated form (Spk) over a wide range of $\mathrm{pH}$ values. Despite this, the sperminium tetracation has only been specified as a ligand in four structures deposited in the PDB (PDB entries 1se6, 1y0q, $1 \mathrm{mg} 9$ and $1 \mathrm{kgk})$, in contrast to $86 \mathrm{PDB}$ entries that indicate an unrealistic neutral form of the ligand (Spm). It should be noted that the bond lengths and angles of Spk and Spm differ appreciably and this distortion is particularly important with high-resolution data.

Although the mode of crystal packing of the Z-DNA molecules in both the $\mathrm{d}(\mathrm{CG})_{3}-\mathrm{Spk}-\mathrm{Mn}^{2+}$ complex and the $\mathrm{d}(\mathrm{CG})_{3}-\mathrm{Spk}-\mathrm{Zn}^{2+}$ complex is of type A (Brzezinski et al., 2011), the single spermine ${ }^{4+}$ tetracation assumes a very different position with respect to the Z-DNA duplex in these structures. The pattern of spermine ${ }^{4+}$ interactions with the DNA duplexes in the $\mathrm{Mn}^{2+}$ complex is most similar to the pattern of spermine ${ }^{4+}$ binding found in other A-type Z-DNA crystals. The entire spermine ${ }^{4+}$ molecule in the $\mathrm{d}(\mathrm{CG})_{3}-\mathrm{Spk}-$ $\mathrm{Mn}^{2+}$ complex is clearly visible in the electron-density map (Fig. 4), which is a rare situation in Z-DNA crystal structures even at very high resolution. The $\mathrm{C} 8$ atom was modelled in two positions with occupancies of 0.52 and 0.48 . The terminal 
atoms C13 and N14 are also disordered in two discrete positions with occupancies of 0.78 and 0.22 . In the $\mathrm{Mn}^{2+}$ complex, as well as in other type A crystals, the Spk cation has the same mode of binding interactions and torsion angles, as listed in Supplementary Table S3.

The general quality of the electron-density maps for the $\mathrm{d}(\mathrm{CG})_{3}-\mathrm{Spk}-\mathrm{Zn}^{2+}$ complex also enabled us to confidently model the sperminium tetracation in relation to the Z-DNA duplexes. However, for one segment of the spermine ${ }^{4+}$ cation (atoms C8-C13) the quality of the electron-density map is poorer than in the Z-DNA- $\mathrm{Mn}^{2+}$ structure, particularly for atoms $\mathrm{C} 8$ and $\mathrm{C} 12-\mathrm{C} 13$.

In both structures the polyamine molecule is shared between Z-DNA duplexes in the crystal lattice, interacting through hydrogen bonds with the phosphate groups and the bases (in the $\mathrm{Mn}^{2+}$ complex only) of the DNA molecules. Interestingly, the spermine ${ }^{4+}$ cation in the $\mathrm{Z}-\mathrm{DNA}-\mathrm{Spk}-\mathrm{Zn}^{2+}$ structure is involved in hydrogen-bonding contacts with the phosphate groups of three duplexes. Two phosphate groups of two neighbouring DNA duplexes are stabilized by hydrogen bonds to the N1 atom, namely OP2 (C9) and OP1 (G6 $\left.6^{\mathrm{iii}}\right)(1-x$, $y+1 / 2,3 / 2-z)$. Two additional N1 . . O hydrogen bonds are formed with water molecules (Wat214 and Wat228). The N5 atom of spermine ${ }^{4+}$ is hydrogen-bonded to Wat219, Wat229 and Wat231. N10 forms hydrogen bonds to OP2(I)/OP2(II) of $\mathrm{G}^{\text {iv }}(1 / 2-x,-y, z+3 / 2)$ and to OP2 of $\mathrm{C}^{\text {iv }}$. Wat238 is hydrogen-bonded to the N14 atom of Spk.

The ability of biogenic polyamines such as spermine to provoke the Z-DNA conformation suggests that these organic cations can act together with other factors, such as inorganic cations, to facilitate a left-handed DNA conformation in vivo. The presence of even a small Z-DNA region within genomic DNA may create a local microstructure with dramatically different properties (Thomas et al., 1991). It is also of note that $(\mathrm{G}-\mathrm{C})_{n}$ cassettes are found in biologically active sequences, e.g. in rodent parvoviruses (Astell et al., 1979) and the histidine D gene of Salmonella (Isono \& Yourno, 1974).

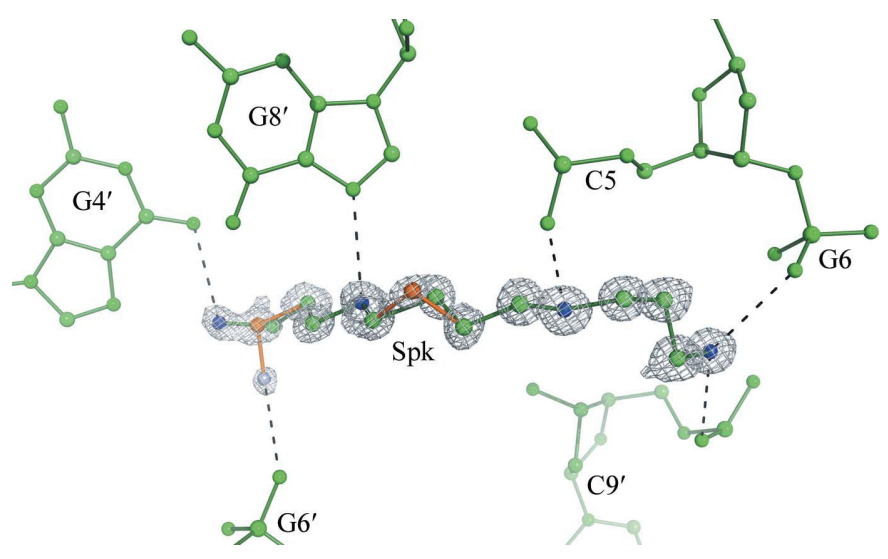

Figure 4

The sperminium tetracation in the crystal structure of the $d(C G)_{3}-S p k-$ $\mathrm{Mn}^{2+}$ complex. The lower occupancy conformation is shown in orange. The $2 F_{\mathrm{o}}-F_{\mathrm{c}}$ map is contoured at the $1 \sigma$ level.
The issue of the conformation of the sperminium tetracation deserves special note. In the $\mathrm{Mn}^{2+}$ complex, the main conformer (I) has a generally extended conformation, with most of the torsion angles (Supplementary Table S3) close to $180^{\circ}$ (trans). The only gauche orientations are assumed at the C6-C7 (near the two-conformer bifurcation at C8) bond $\left(-67.76^{\circ}\right)$ and the far end terminal C12-C13 $\left(62.18^{\circ}\right)$. In the alternative conformation II the far end has the opposite gauche conformation $\left(-76.30^{\circ}\right)$, while the N5-C6-C7-C8(II)C9-N10 segment has been modelled with two 'impossible' eclipsed torsion angles: $-107.55^{\circ}$ (C6-C7) and $-120.77^{\circ}$ [C8(II)-C9]. Numerous efforts to model these torsion angles in the standard staggered form were unsuccessful, and the only plausible interpretation of the electron density (Fig. 4), and also of OMIT maps (not shown), was with a model as included in Supplementary Table S3. We must conclude therefore that a minor fraction of the Spk molecules in the crystal assume an unfavourable conformation, consequently leading to disorder. Such disorder is more pronounced in the $\mathrm{Zn}^{2+}$ complex structure, in which the Spk cation is partially invisible in the electron-density maps. We note here that the situation of Spk in an unfavourable eclipsed conformation has been reported previously, for instance in the highest resolution metal-free Z-DNA structure 3p4j (Brzezinski et al., 2011).

\subsection{Hydration}

The metal complexes described in this work are similar to other high-resolution Z-DNA structures from the point of view of the architecture of the hydration shells, which contain complicated hydrogen-bonded networks that stabilize the conformation of the DNA molecules and crystal packing. A total of 88 and 77 water-molecule sites were found in the asymmetric units of the $\mathrm{d}(\mathrm{CG})_{3}-\mathrm{Spk}_{-}-\mathrm{Mn}^{2+}$ and the $\mathrm{d}(\mathrm{CG})_{3}-$ $\mathrm{Spk}-\mathrm{Zn}^{2+}$ complexes, respectively. All water molecules were refined anisotropically without positional restraints. With respect to their occupancy parameters, those water molecules for which the occupancies converged on refinement to values close to unity $(>0.93)$ had their occupancies fixed at 1.0 (32 sites in the $\mathrm{Mn}^{2+}$ complex and 38 sites in the $\mathrm{Zn}^{2+}$ complex). Close pairs of sites for which the sum of their refined occupancies converged close to unity (21 and four pairs, respectively) had their combined occupancy constrained to 1.0. The remaining sites (35 in both structures) had their occupancies refined freely to fractional values. A large number of the water sites are therefore only partially occupied and they are often situated in proximity at alternative disordered locations. Summation of all the water occupancies in the asymmetric unit gives total water contents of 77.5 and 62.1 molecules in the crystals of $\mathrm{d}(\mathrm{CG})_{3}-\mathrm{Spk}-\mathrm{Mn}^{2+}$ and $\mathrm{d}(\mathrm{CG})_{3}-\mathrm{Spk}-\mathrm{Zn}^{2+}$, respectively, which can be compared with the 78.6 water molecules identified in the asymmetric unit of the metal-free spermine ${ }^{4+}$ form Z-DNA structure (also A-type) determined at $0.55 \AA$ resolution (Brzezinski et al., 2011). This result illustrates the known fact that the atomic interpretation of the solvent region in macromolecular crystals improves with resolution. However, as the example of the $\mathrm{Mn}^{2+}$ complex suggests, there 
is very little improvement in the interpretation of the solvent structure when the resolution is extended beyond $0.75 \AA$.

Some characteristic features of the solvent structure in Z-DNA crystals, namely the spine of hydration, water bridges between the guanine $\mathrm{N} 2$ amino groups and phosphate $\mathrm{O}$ atoms, and water molecules bound to the backbone for structural stability, are present in both structures. However, there is an evident absence of the spine of hydration between the base pairs C5.G8 and C7.G6 in the d(CG) ${ }_{3}-\mathrm{Spk}-\mathrm{Mn}^{2+}$ structure and at $\mathrm{C} 1 \cdot \mathrm{G} 12, \mathrm{C} 6 \cdot \mathrm{G} 7$ and $\mathrm{C} 11 \cdot \mathrm{G} 2$ in the $\mathrm{d}(\mathrm{CG})_{3}-$ $\mathrm{Spk}-\mathrm{Zn}^{2+}$ structure. There are no water molecules hydrogenbonded to the guanine N3 atoms in any of the complexes. Typically, the O6 atoms of the guanine moieties form hydrogen bonds to two water molecules. Furthermore, one water molecule in each structure bridges two guanine bases

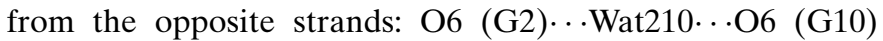
(in the $\mathrm{Mn}^{2+}$ complex) and O6 (G4)...Wat233...O6 (G8) (in the $\mathrm{Zn}^{2+}$ complex). There are also water-mediated hydrogen bonds between the sugar backbone and the sperminium cation, O4' (G6) ‥Wat...N1 (Spk), in both complexes.

Besides the two most prominent peaks for $\mathrm{Zn}^{2+}(1)$ and $\mathrm{Zn}^{2+}(2)$, the anomalous difference map for the $\mathrm{Zn}^{2+}$ complex also exhibits a third peak $(\sim 6.2 \sigma)$ which coincides with electron density near the N7 (G4) atom. However, an additional $\mathrm{Zn}^{2+}$ cation placed at the position of this peak in the $2 F_{\mathrm{o}}-F_{\mathrm{c}}$ map refines with an occupancy below 0.20 . Therefore, Wat232 was modelled to interpret the $2 F_{\mathrm{o}}-F_{\mathrm{c}}$ peak near N7 (G4) with an occupancy of 1.0 after refinement. However, we note

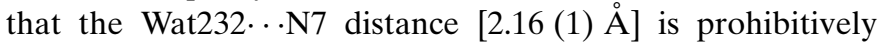
short.

\subsection{Crystal packing}

Two different packing modes (denoted A and B) within the same $P 2_{1} 2_{1} 2_{1}$ symmetry have been identified in the crystal structures of left-handed $\mathrm{d}(\mathrm{CG})_{3}$ Z-DNA duplexes. The difference between those two non-isomorphous modes is in the interhelical interaction of the Z-DNA duplexes, which are situated (with a different shift and rotation) along the $z$ screw axis. The occurrence of a particular crystal form of $\left[\mathrm{d}(\mathrm{CG})_{3}\right]_{2}$ is not fully correlated with the presence of spermine ${ }^{4+}$ or metal ions. The crystal packing of the two crystal structures presented here is of type A (Brzezinski et al., 2011). However, the interactions of the spermine ${ }^{4+}$ molecules with the Z-DNA duplexes are entirely different in the two structures (see above).

\section{Discussion}

In this work, we have presented two new crystal structures of the sperminium form of Z-DNA in complexes with $\mathrm{Mn}^{2+}$ and $\mathrm{Zn}^{2+}$ ions. The structures have the highest resolution and accuracy of the refined parameters among all of the Z-DNA complexes with transition-metal cations deposited in the PDB. Our results are of special importance as only very few crystal structures of Z-DNA in complex with transition-metal ions have been deposited in the structural databases. The complexes were obtained within a larger project aimed at studying the effect of transition metals on the fine structure of DNA duplexes, particularly in the left-handed Z-DNA form, and at studying the differences in metal coordination by DNA. The structures of both complexes were determined at ultrahigh resolution and concluded with a full-matrix least-squares refinement, providing a wealth of very accurate structural data together with error estimates. The DNA moieties of the $\mathrm{d}(\mathrm{CG})_{3}-\mathrm{Spk}-\mathrm{Mn}^{2+}$ and $\mathrm{d}(\mathrm{CG})_{3}-\mathrm{Spk}-\mathrm{Zn}^{2+}$ complexes have an overall structure similar to previously described structures of $\mathrm{d}(\mathrm{CG})_{3}$ Z-DNA (see, for example, Egli et al., 1991; Schneider et al., 1992; Ho \& Mooers, 1997; Harper et al., 1998; Brzezinski et al., 2011). However, in spite of the evidence of high regularity and rigidity of Z-DNA helices in the absence of metal cations (Brzezinski et al., 2011), the variability observed in the DNA structure of the present complexes suggests that changes in the ionic environment (ionic strength, type of metal cation and $\mathrm{pH}$ ) of the Z-DNA may have a significant impact on the conformational flexibility of the sugar-phosphate backbone as well as on the position of the polyamine polycation and its mode of interaction with the DNA duplexes. In particular, in the $\mathrm{Zn}^{2+}$ complex the DNA backbone is destabilized to such an extent that it assumes a double conformation in several segments. In this context, it is quite interesting that despite many years of crystallographic study of the Z-DNA duplex with the $\mathrm{d}(\mathrm{CG})_{3}$ sequence, experimental X-ray data, particularly at high resolution, still reveal novel previously unobserved details of the structure. In most structures of $d(C G)_{3}$ Z-DNA the $\mathrm{Z}_{\mathrm{II}^{-}}$-type conformation is found at the same G4-C5 position (Harper et al., 1998), although in a few cases it was observed at positions $2-3,8-9$ or $10-11$. In the present complexes the $\mathrm{Z}_{\mathrm{II}}$ conformation is found at its typical position at G4-C5 and also at the less common G10-C11 site in the $\mathrm{Zn}^{2+}$ complex. The alternate (I and II) backbone conformations in the $\mathrm{Zn}^{2+}$ complex preserve the $\mathrm{Z}$ form in both variants. This is in contrast to other structures with disorder, which have $\mathrm{Z}_{\mathrm{I}}$ and $\mathrm{Z}_{\mathrm{II}}$ conformations of the phosphate groups at the alternate sites (Wang et al., 1981; Harper et al., 1998; Bharanidharan et al., 2007).

Hydrated $\mathrm{Mg}^{2+}$ and $\mathrm{Mn}^{2+}$ cations in Z-DNA complexes have metal-Wat and metal-N7 (guanine) bonds of similar lengths in their octahedral coordination spheres. The $\mathrm{Mn}^{2+}$ Wat bond distances, which are between 1.946 (34) and 2.310 (20) $\AA$, fall into a similar range as those for $\mathrm{Mg}^{2+}$ ions (1.99-2.29 Aं; Gessner et al., 1989). In the Z-DNA structures with hydrated $\mathrm{Mg}^{2+}$ ions, the water molecule with the longest $\mathrm{Mg}^{2+}$-Wat distance forms a hydrogen bond to the $\mathrm{O} 1$ atom of the preceding (with respect to the G6 residue in the coordination sphere) phosphate group. In the present $\mathrm{Mn}^{2+}$ complex the situation is exactly the opposite. The octahedral coordination sphere of $\mathrm{Mn}^{2+}$ differs from the octahedral coordination sphere of $\mathrm{Zn}^{2+}(1)$ owing to the alternative locations of several water molecules around the $\mathrm{Mn}^{2+}$ ion. Our observation of a distorted octahedral geometry for the $\mathrm{Mn}^{2+}$ ion is consistent with previous findings (Borgstahl et al., 2000; Millonig et al., 2009). Wat210 from the hydration sphere of $\mathrm{Zn}^{2+}$ (1) forms an additional hydrogen bond to the OP2 (C5) 
Table 4

Details of Z-DNA-Mn ${ }^{2+}$ interactions.

Atoms from symmetry-related molecules are denoted by an asterisk.

\begin{tabular}{|c|c|c|c|c|c|c|c|}
\hline $\begin{array}{l}\text { PDB } \\
\text { code }\end{array}$ & $\begin{array}{l}\text { Resolution } \\
(\AA)\end{array}$ & $\begin{array}{l}R \\
(\%)\end{array}$ & Cation & Occupancy & $\begin{array}{l}B_{\text {iso }} \\
\left(\AA^{2}\right)\end{array}$ & Ligand & $\begin{array}{l}\text { Distance } \\
(\AA)\end{array}$ \\
\hline \multirow{9}{*}{$\begin{array}{l}\text { This } \\
\text { work }\end{array}$} & \multirow[t]{9}{*}{0.75} & \multirow[t]{9}{*}{7.06} & \multirow[t]{9}{*}{$\mathrm{Mn}^{2+}$} & \multirow[t]{9}{*}{1.00} & \multirow[t]{9}{*}{$1.89 \dagger$} & N7 (G6) & 2.257 \\
\hline & & & & & & Wat203a & 2.075 \\
\hline & & & & & & Wat203b & 2.310 \\
\hline & & & & & & Wat216a & 2.186 \\
\hline & & & & & & Wat216b & 2.255 \\
\hline & & & & & & Wat250a & 2.207 \\
\hline & & & & & & Wat250b & 1.946 \\
\hline & & & & & & Wat251 & 2.158 \\
\hline & & & & & & Wat252 & 2.138 \\
\hline \multirow[t]{8}{*}{$3 \mathrm{fq} 5$} & \multirow[t]{8}{*}{2.80} & \multirow[t]{8}{*}{16.70} & \multirow[t]{4}{*}{$\mathrm{Mn}^{2+}(1)$} & \multirow[t]{4}{*}{1.00} & \multirow{4}{*}{22.30} & N7 (A2) & 2.47 \\
\hline & & & & & & N7 (G10) & 2.41 \\
\hline & & & & & & OP1 (T11*) & 2.30 \\
\hline & & & & & & Wat & 2.52 \\
\hline & & & \multirow[t]{4}{*}{$\mathrm{Mn}^{2+}(2)$} & \multirow[t]{4}{*}{1.00} & \multirow[t]{4}{*}{37.91} & N7 (G4) & 2.21 \\
\hline & & & & & & N7 (G6*) & 2.57 \\
\hline & & & & & & O6 (G6*) & 3.18 \\
\hline & & & & & & Wat & 2.23 \\
\hline \multirow[t]{4}{*}{$3 \mathrm{~g} 2 \mathrm{r}$} & \multirow[t]{4}{*}{2.15} & \multirow[t]{4}{*}{26.90} & \multirow[t]{4}{*}{$\mathrm{Mn}^{2+}$} & \multirow[t]{4}{*}{0.25} & \multirow[t]{4}{*}{35.16} & O6 (G2) & 2.44 \\
\hline & & & & & & $\mathrm{O} 6(\mathrm{G} 2 *)$ & 2.44 \\
\hline & & & & & & $\mathrm{O} 4$ (T3) & 3.47 \\
\hline & & & & & & $\mathrm{O} 4(\mathrm{~T} 3 *)$ & 3.41 \\
\hline \multirow[t]{12}{*}{ 4dwy } & \multirow[t]{12}{*}{1.61} & \multirow[t]{12}{*}{20.30} & \multirow[t]{6}{*}{$\mathrm{Mn}^{2+}(1)$} & \multirow[t]{6}{*}{1.00} & 12.88 & N7 (A2) & 2.36 \\
\hline & & & & & & N7 (G4) & 2.28 \\
\hline & & & & & & OP1 (T11*) & 2.09 \\
\hline & & & & & & Wat & 2.23 \\
\hline & & & & & & Wat & 2.29 \\
\hline & & & & & & Wat & 2.30 \\
\hline & & & $\mathrm{Mn}^{2+}(2)$ & 0.70 & 20.17 & N7 (G4) & 2.45 \\
\hline & & & & & & O6 (G4) & 2.47 \\
\hline & & & & & & N7 (G12*) & 2.31 \\
\hline & & & & & & Wat & 2.12 \\
\hline & & & & & & Wat & 2.27 \\
\hline & & & & & & Wat & 2.40 \\
\hline $4 \mathrm{dy} 8$ & 1.76 & 22.70 & $\mathrm{Mn}^{2+}(a)$ & 0.65 & 24.81 & O6 (G4) & 2.74 \\
\hline & & & & & & N7 (G4) & 2.94 \\
\hline & & & $\mathrm{Mn}^{2+}(b)$ & 0.35 & 26.77 & O6 (G16) & 2.57 \\
\hline & & & & & & N7 (G16) & 3.04 \\
\hline
\end{tabular}

$\dagger B_{\text {eq }}$.

atom, in contrast to the hydration sphere of $\mathrm{Mn}^{2+}$, in which the OP2 (C5) atom is engaged in a hydrogen bond to the N5 atom of Spk. This difference in the formation of hydrogen bonds to water or Spk is correlated with the values of the backbone $\beta$ angles at $\mathrm{C} 5$ in the $\mathrm{d}(\mathrm{CG})_{3}-\mathrm{Spk}-\mathrm{Zn}^{2+}\left(146.6^{\circ}\right)$ and $\mathrm{d}(\mathrm{CG})_{3}-$ Spk- $\mathrm{Mn}^{2+}\left(170.1^{\circ}\right)$ complexes.

In addition to the $\mathrm{d}(\mathrm{CG})_{3}$ hexamer discussed here, $\mathrm{Mn}^{2+}$ ions have also been located in four Z-DNA structures (one in space group $C 222_{1}$, one in space group $P 6_{5}$ and two in space group $P 2_{1}$ ) with the sequence $5^{\prime}$-d(CACGCG).3'-d(CGCGTG). These structures, with PDB codes 4dwy, 4dy8, 3g2r and $3 \mathrm{fq} 5$, were determined at resolutions of 1.61, 1.76, 2.15 and $2.80 \AA$, respectively (Mandal et al., 2012). In the 3g2r, $3 \mathrm{fq} 5$ and 4dwy structures the $\mathrm{Mn}^{2+}$ cation is bis-coordinated and in the 4dy8 structure $\mathrm{Mn}^{2+}$ was modelled as a disordered ion in two positions. An octahedral geometry can be only assigned to the coordination sphere around $\mathrm{Mn}^{2+}(1)$ in the 4dwy structure. The $\mathrm{Mn}^{2+}$-ligand distances are generally longer for the previous $\mathrm{Z}-\mathrm{DNA}-\mathrm{Mn}^{2+}$ complexes than in the present $\mathrm{d}(\mathrm{CG})_{3}-\mathrm{Spk}-\mathrm{Mn}^{2+}$ structure (Table 4). The differences in the coordination spheres between the deposited $5^{\prime}$-d(CACGCG). $3^{\prime}$-d(CGCGTG) hexamers with $\mathrm{Mn}^{2+}$ ions and the present $\mathrm{d}(\mathrm{CG})_{3}-\mathrm{Spk}-\mathrm{Mn}^{2+}$ duplex can be explained by different crystal packing (Mandal et al., 2012). Several differences in the conformation of the DNA moieties are also observed between the present and the previous structures of Z-DNA in complex with $\mathrm{Mn}^{2+}$. As is the case in most $\mathrm{d}(\mathrm{CG})_{3}$ structures, the nucleotide moieties in the $\mathrm{d}(\mathrm{CG})_{3}-\mathrm{Spk}-\mathrm{Mn}^{2+}$ complex have $\mathrm{C} 2$ '-endo (pyrimidines) and $\mathrm{C}^{\prime}$-endo (purines) sugar puckers, except for the $3^{\prime}$-terminal guanosines, which are also $\mathrm{C} 2$ '-endo. On the other hand, in the previously described Z-DNA- $\mathrm{Mn}^{2+}$ structures the pseudorotation angles have a wider range and several nucleotides assume one of the $\mathrm{C1}^{\prime}$-exo, $\mathrm{C}^{\prime}$-exo, $\mathrm{C} 4{ }^{\prime}$-exo, $\mathrm{O} 4{ }^{\prime}$-exo or $\mathrm{O} 4{ }^{\prime}$-endo sugar-pucker modes.

Conformation $Z_{\text {II }}$ was not only observed for the 4-5 position (in structure $3 \mathrm{fq} 5$, as in this work) but was also adopted by the DNA backbone at positions 8-9 and 10-11 in structures $4 \mathrm{dy} 8$ and $4 \mathrm{dwy}$, respectively. In contrast to the previous complexes, in which the $\mathrm{Mn}^{2+}$ ion made interactions with two DNA bases (in a nonsimultaneous fashion in structure 4dy8), in the present complex the manganese cation is coordinated by only one base residue. Large $x$-displacement values are observed in the structures 3fq5, 4dwy and 4dy8 (-56.8, 61.3 and $-98.0 \AA$, respectively) at the base steps where an $\mathrm{Mn}^{2+}$ ion is located between two bases. Such a significant effect (a pushing of the bases away from the helix axis) is absent in the present $\mathrm{d}(\mathrm{CG})_{3}-\mathrm{Spk}-\mathrm{Mn}^{2+}$ complex, where the values of $x$ displacement are in the same range as for most Z-DNA structures with the $\mathrm{d}(\mathrm{CG})_{3}$ sequence.

The location of the sperminium tetracation along the DNA backbone in the structure of the $\mathrm{Zn}^{2+}$ complex allows it to form hydrogen bonds to phosphate groups only. Such an arrangement of the Spk tetracation has been observed previously for the $\mathrm{d}\left[\mathrm{CGT}\left(2-\mathrm{NH}_{2}-\mathrm{A}\right) \mathrm{CG}\right]_{2}$ duplex, which crystallized in space group $P 3_{2} 21$ (Parkinson et al., 1995). It is an interesting observation that in spite of the same crystal packing, crystallization conditions and soaking protocol, the Spk tetracation forms completely different patterns of interactions with the Z-DNA in the two complexes described in this work. To date, no such difference in the position of Spk relative to the DNA lattice has been reported for the crystal structures of Z-DNA deposited in the PDB that have crystal packing of type A and contain only one Spk molecule. Since the two metal complexes were generated from the same metalfree crystals using the same soaking procedure, it is logical to conclude that the rearrangement of the sperminium tetracation took place during the soaking experiment and was influenced by the identity of the metal cation. It can therefore be assumed that the pattern of interactions between Spk and DNA can be related to the physicochemical properties of the $\mathrm{Mn}^{2+}$ and $\mathrm{Zn}^{2+}$ ions. The differences between these transitionmetal ions could affect the competition between the metal cation and Spk during the process of docking in the Z-DNA framework. This hypothesis requires further studies with other biogenic polyamines and transition-metal cations and using a wider range of conditions during the soaking or crystallization experiments. Such experiments may be of special interest as 
a way of addressing the problems of interactions of organic and inorganic cations with biological macromolecules in vivo (Fraustro da Silva \& Williams, 2001).

Our studies of Z-DNA-Spk-metal cation complexes confirm the view that the Z-DNA duplexes can undergo local conformational changes, as indicated in previous investigations (Wang et al., 1981; Eichman et al., 1999; Bharanidharan et al., 2007; Mandal et al., 2008) and that these changes can be triggered by metal cations. The high-resolution structures described in this work provide important and accurate information about the impact of transition-metal cations on the structure of Z-DNA and about the geometrical parameters characterizing the coordination of biologically relevant metal cations by DNA.

The authors thank Karolina Michalska and Jakub Barciszewski for their help at the EMBL/DESY beamlines. RK is the recipient of National Science Center grants UMO-2011/03/ B/NZ1/00576 and UMO-2011/03/B/ST5/0109.

\section{References}

Allen, F. H. (2002). Acta Cryst. B58, 380-388.

Allen, F. H., Watson, D. G., Brammer, L., Orpen, A. G. \& Taylor, R. (2006). International Tables for Crystallography, Vol. C, pp. 790811. Dordrecht: Kluwer Academic Publishers.

Astell, C. R., Smith, M., Chow, M. B. \& Ward, D. C. (1979). Cell, 17, 691-703.

Bae, S., Kim, D., Kim, K. K., Kim, Y.-G. \& Hohng, S. (2011). J. Am. Chem. Soc. 133, 668-671.

Bancroft, D., Williams, L. D., Rich, A. \& Egli, M. (1994). Biochemistry, 33, 1073-1086.

Berman, H. M., Olson, W. K., Beveridge, D. L., Westbrook, J., Gelbin, A., Demeny, T., Hsieh, S.-H., Srinivasan, A. R. \& Schneider, B. (1992). Biophys. J. 63, 751-759.

Berman, H. M., Westbrook, J., Feng, Z., Gilliland, G., Bhat, T. N., Weissig, H., Shindyalov, I. N. \& Bourne, P. E. (2000). Nucleic Acids Res. 28, 235-242.

Bharanidharan, D., Thiyagarajan, S. \& Gautham, N. (2007). Acta Cryst. F63, 1008-1013.

Bock, C. W., Katz, A. K., Markham, G. D. \& Glusker, J. P. (1999). J. Am. Chem. Soc. 121, 7360-7372.

Borgstahl, G. E., Pokross, M., Chehab, R., Sekher, A. \& Snell, E. H. (2000). J. Mol. Biol. 296, 951-959.

Brehler, B. (1961). Z. Kristallogr. 115, 373-402.

Brünger, A. T. (1992). Nature (London), 355, 472-475.

Brzezinski, K., Brzuszkiewicz, A., Dauter, M., Kubicki, M., Jaskolski, M. \& Dauter, Z. (2011). Nucleic Acids Res. 39, 6238-6248.

Bujacz, G., Jaskolski, M., Alexandratos, J., Wlodawer, A., Merkel, G., Katz, R. A. \& Skalka, A. M. (1996). Structure, 15, 89-96.

Clowney, L., Jain, S. C., Srinivasan, A. R., Westbrook, J., Olson, W. K. \& Berman, H. M. (1996). J. Am. Chem. Soc. 118, 509-518.

Cowan, J. A. (1998). Chem. Rev. 98, 1067-1088.

Cromer, D. T. (1983). J. Appl. Cryst. 16, 437.

DeLano, W. L. (2002). PyMOL. http://www.pymol.org.

Egli, M., Williams, L. D., Gao, Q. \& Rich, A. (1991). Biochemistry, 30, 11388-11402.

Eichman, B. F., Schroth, G. P., Basham, B. E. \& Ho, P. S. (1999). Nucleic Acids Res. 27, 543-550.

Emsley, P., Lohkamp, B., Scott, W. G. \& Cowtan, K. (2010). Acta Cryst. D66, 486-501.

Feng, Z., Westbrook, J. \& Berman, H. M. (1998). Report NDB-407. Rutgers University, New Brunswick, New Jersey, USA.
Fraustro da Silva, J. J. R. \& Williams, R. J. P. (2001). The Biological Chemistry of the Elements: The Inorganic Chemistry of Life, p. 265. Oxford University Press.

Gao, Y.-G., Sriram, M. \& Wang, A. H.-J. (1993). Nucleic Acids Res. 21, 4093-4101.

Geierstanger, B. H., Kagawa, T. F., Chen, S.-L., Quigley, G. J. \& Ho, P. S. (1991). J. Biol. Chem. 266, 20185-20191.

Gelbin, A., Schneider, B., Clowney, L., Hsieh, S., Olson, W. K. \& Berman, H. M. (1996). J. Am. Chem. Soc. 118, 519-529.

Gessner, R. V., Frederick, C. A., Quigley, G. J., Rich, A. \& Wang, A. H.-J. (1989). J. Biol. Chem. 264, 7921-7935.

Gessner, R. V., Quigley, G. J., Wang, A. H.-J., van der Marel, G. A., van Boom, J. H. \& Rich, A. (1985). Biochemistry, 24, 237-240.

Harper, A., Brannigan, J. A., Buck, M., Hewitt, L., Lewis, R. J., Moore, M. H. \& Schneider, B. (1998). Acta Cryst. D54, 12731284

Ho, P. S., Frederick, C. A., Saal, D., Wang, A. H.-J. \& Rich, A. (1987). J. Biomol. Struct. Dyn. 4, 521-534.

Ho, P. S. \& Mooers, B. H. M. (1997). Biopolymers, 44, 65-90.

Isono, K. \& Yourno, J. (1974). Proc. Natl Acad. Sci. USA, 71, 16121617.

Jaskólski, M. (1984). Acta Cryst. A40, 364-366.

Jean, Y.-C., Gao, Y.-G. \& Wang, A. H.-J. (1993). Biochemistry, 32, 381-388.

Kabsch, W. (2010). Acta Cryst. D66, 125-132.

Kagawa, T. F., Geierstanger, B. H., Wang, A. H.-J. \& Ho, P. S. (1991). J. Biol. Chem. 266, 20175-20184.

Kleywegt, G. J. \& Jones, T. A. (1996). Acta Cryst. D52, 826-828.

Lomozik, L., Gasowska, A., Bregier-Jarzebowska, R. \& Jastrzab, R. (2005). Coord. Chem. Rev. 249, 2335-2350.

Lu, X.-J. \& Olson, W. K. (2003). Nucleic Acids Res. 31, 5108-5121.

Mandal, P. K., Venkadesh, S. \& Gautham, N. (2008). J. Indian Inst. Sci. 88, 73-93.

Mandal, P. K., Venkadesh, S. \& Gautham, N. (2012). Acta Cryst. F68, 1420-1426.

McCoy, A. J., Grosse-Kunstleve, R. W., Adams, P. D., Winn, M. D., Storoni, L. C. \& Read, R. J. (2007). J. Appl. Cryst. 40, 658-674.

Millonig, H., Pous, J., Gouyette, C., Subirana, J. A. \& Campos, J. L. (2009). J. Inorg. Biochem. 103, 876-880.

Murshudov, G. N., Skubák, P., Lebedev, A. A., Pannu, N. S., Steiner, R. A., Nicholls, R. A., Winn, M. D., Long, F. \& Vagin, A. A. (2011). Acta Cryst. D67, 355-367.

Parkinson, G. N., Arvanitis, G. M., Lessinger, L., Ginell, S. L., Jones, R., Gaffney, B. \& Berman, H. M. (1995). Biochemistry, 34, 1548715495.

Parkinson, G., Vojtechovsky, J., Clowney, L., Brünger, A. T. \& Berman, H. M. (1996). Acta Cryst. D52, 57-64.

Schneider, B., Ginell, S. L., Jones, R., Gaffney, B. \& Berman, H. M. (1992). Biochemistry, 31, 9622-9628.

Sheldrick, G. M. (2008). Acta Cryst. A64, 112-122.

Subirana, J. A. \& Soler-Lopez, M. (2003). Annu. Rev. Biophys. Biomol. Struct. 32, 27-45.

Svozil, D., Kalina, J., Omelka, M. \& Schneider, B. (2008). Nucleic Acids Res. 36, 3690-3706.

Tereshko, V., Wilds, C. J., Minasov, G., Prakash, T. P., Maier, M. A., Howard, A., Wawrzak, Z., Manoharan, M. \& Egli, M. (2001). Nucleic Acids Res. 29, 1208-1215.

Thiyagarajan, S., Rajan, S. S. \& Gautham, N. (2005). Acta Cryst. D61, $1125-1131$.

Thomas, T. J., Gunnia, U. B. \& Thomas, T. (1991). J. Biol. Chem. 266, 6137-6141.

Wang, A. H.-J., Quigley, G. J., Kolpak, F. J., van der Marel, G., van Boom, J. H. \& Rich, A. (1981). Science, 211, 171-176.

Winn, M. D., Long, F. \& Vagin, A. A. (2011). Acta Cryst. D67, 235-242 Xia, T., SantaLucia, J., Burkard, M. E., Kierzek, R., Schroeder, S. J., Jiao, X., Cox, C. \& Turner, D. H. (1998). Biochemistry, 37, 1471914735. 